\title{
Antioxidant Activity, Rutin Content and Genetic Similarity Between Matrices and Progenies of Hancornia speciosa
}

\author{
Caroline de Araújo Machado ${ }^{1}$, Leila Albuquerque Resende de Oliveira ${ }^{1}$, Annie Carolina Araújo de Oliveira ${ }^{1}$, \\ Milena Nascimento Cardoso ${ }^{1}$, Francine Ferreira Padilha ${ }^{2}$, Bruno Trindade Cardoso ${ }^{3}$, Ana Veruska Cruz da Silva ${ }^{3}$ \\ \& Ana da Silva Ledo ${ }^{3}$ \\ ${ }^{1}$ Programa de Pós-graduação em Agricultura e Biodiversidade, Universidade Federal de Sergipe, São Cristóvão, \\ Sergipe, Brazil \\ ${ }^{2}$ Programa de Pós-graduação em Biotecnologia Industrial, Universidade Tiradentes, Aracaju, Sergipe, Brazil \\ ${ }^{3}$ Universidade Federal de Lavras, Lavras, Minas Gerais, Brazil \\ ${ }^{4}$ Embrapa Tabuleiros Costeiros, Aracaju, Sergipe, Brazil \\ Correspondence: Caroline de Araújo Machado, Programa de Pós-graduação em Agricultura e Biodiversidade, \\ Universidade Federal de Sergipe, Av. Marechal Rondon s/n, São Cristóvão, Sergipe, Brazil. Tel: \\ 55-79-999-199-119. E-mail: camachado@hotmail.com
}

Received: May 8, 2018

Accepted: June 24, $2018 \quad$ Online Published: August 15, 2018

doi:10.5539/jas.v10n9p344

URL: https://doi.org/10.5539/jas.v10n9p344

\begin{abstract}
Mangaba tree (Hancornia speciosa Gomes) is a tropical fruit species from Brazil and presents socioeconomic potential. The objective of this study was to determine antioxidant activity, rutin content and genetic similarity among in vivo and in vitro matrices and progenies of six accessions from the Mangaba Active Germplasm Bank of the Embrapa Coastal Tablelands, SE, Brazil. Young leaves of adult matrix plants and in vitro callus methanolic extracts obtained from young leaves resulted in differences between the accessions for the rutin content and high antioxidant activity. The Costa Azul accession, from Bahia, Brazil outstood with values above 3,000 $\mathrm{g}$ of dry extract/g of DPPH (2.2-diphenyl-1-picrilhydrazyl) in in vitro callus coming from nodal and internodal segments $(3,023.73$ and 3,136.80 g of dry extract/g of DPPH, respectively). Rutin was not found in extracts resulting from in vitro callus of mangaba tree. The difference among the values obtained for DPPH analysis are superior when compared with in vivo leaf extract, with the in vitro Costa Azul accession (nodal and internodal) outstanding, concluding that in vitro callus induction can interfere with chemical compounds of the plant. The markers detect genetic similarity under in vitro cultivation conditions. The Costa Azul accession group itself in isolation from others and $\mathrm{EC}_{50}$ concentrations differentiated between leaf and callus are obtained. $\mathrm{O} \mathrm{EC}_{50}$ is superior in extracts deriving from in vitro callus, with the in vitro Costa Azul accession (nodal and internodal).
\end{abstract}

Keywords: HPLC, ISSR, DPPH, callogenesis

\section{Introduction}

The mangaba tree (Hancornia speciosa Gomes) is a Brazilian fruit species, belonging to the Apocynaceae family (Silva et al., 2017). It presents great market potential within the tropical fruits segment. The fruit (mangaba) is very important for the Brazilian agroindustry, especially in the northeastern region (Santos et al., 2017). Besides this, mangaba tree present potential for recovery of degraded areas, allowing its sustainable use, also serving as a source of alternative income for local populations (Oliveira et al., 2016).

According to data from IBGE (Brazilian Institute of Geography and Statistics) (2016) presented extractive production of 922 tons of mangaba and, in 2015, 663 tons, an increase of $39.1 \%$. The total national production, Sergipe is in fourth place, this fact was caused by the $33 \%$ reduction of the mangaba collectors and due to the real estate advance in areas of natural production of this species. However, the increase in production in other states is considered due to its fruitful potential, being one of the cerrado species with greater chances of being studied aiming its conservation.

The medicinal properties of mangaba have been reported by some authors. Antihypertensive activity potential demonstrated in in vitro studies for the angiotensin-converting enzyme (ACE) inhibition to the ethanolic extraction of leaves (Serra et al., 2005) and endothelium-dependent vasodilatation activity, via nitric oxide, in in 
vitro preparations of aortic rings, also for ethanolic extraction of leaves of the species (Ferreira et al., 2007). It is possible that the bioactive molecules present in the aqueous extract of Hancornia speciosa fruits bind to receptors of endothelial cells, inhibiting the cell migration and the activation of inflammatory mediators involved in chemotaxis and diapedesis (Torres-Rêgo et al., 2016).

The production of secondary metabolites employing plant cell culture has been extensively studied, constituting a suitable system to produce important pharmacological compounds (Morais et al., 2012). The in vitro culture of plant cells presents advantages for the supply of bioactive compounds with defined production system and short culture periods, ensures a continuous supply of metabolites of interest, and the cells are free of diseases and are not exposed to seasonal variations (Castro et al., 2016). Manipulations of in vitro nutritional components and physical factors are the main factors for the culture productivity optimization (Fazal et al., 2016). Studies on the chemical composition, antioxidant activity and volatile compounds of mangaba are scarce (Lima et al., 2015). Some studies demonstrated high antioxidant activity in mangaba fruits, those observed in other fruit species such as Anacardium occidentale (St. Hilaire), Spondias tuberosa (Arr. Cam.) and Euterpe oleracea (Mart) (Rufino et al., 2010).

The reproductive system of the tree species is one of the most decisive factors for the maintenance of genetic variability among individuals of a population. Populations that present cross-fertilization have greater possibilities of increasing the genetic variability without adding new genes when compared with the population of individuals that perform self-fertilization (Borges et al., 2009). In addition, the phenotypic variation is strongly influenced by environmental components such as anthropological level, soil condition, climate, age of plants and genetic differences between individuals. While the species are not yet fully domestic, variability is an important factor to enable the plant selection for the establishment of orchards with greater uniformity and specific characteristics (Yokomizo et al., 2017). Thus, was aimed with this study to evaluate the antioxidant activity, the rutin content and genetic similarity between in vivo and in vitro matrices and progenies of six accessions from the Mangaba Active Germplasm Bank of the Embrapa Coastal Tablelands, SE, Brazil.

\section{Material and Methods}

\subsection{Local and Plant Material}

The experiments were conducted in the laboratories of Plant Tissue Culture and Molecular Biology of Embrapa Coastal Tablelands and in the laboratory of Biomaterials from Center of Colloidal System StudyTechnological Institute of Research, Tiradentes University, in Aracaju, Sergipe, Brazil.

Six accessions were selected from the Mangaba Active Germplasm Bank, located in Itaporanga d'Ajuda, SE, Brazil $\left(11^{\circ} 06^{\prime} 40^{\prime \prime} \mathrm{S}\right.$ and $\left.37^{\circ} 11^{\prime} 15^{\prime \prime} \mathrm{W}\right)$. All plant matrices were in the same environmental conditions, and the fruits were collected in the summer for seed excision. After 30 days the seeds grown in vitro were germinated, to obtain callus deriving from leaf, nodal and intermodal segments. For the in vivo analysis of mangaba leaves, $50 \mathrm{~g}$ of leaves of 3 plants of each accession (Table 1).

Table 1. Accessions evaluated from the Mangaba Active Germplasm Bank. Embrapa Coastal Tablelands, Aracaju, Sergipe, Brazil

\begin{tabular}{lll}
\hline Accessions & Origin (Municipality-State) & Geographic Coordinates \\
\hline AB & Água Boa-Sergipe & $0^{\circ} 46^{\prime} 31^{\prime \prime} \mathrm{S} ; 48^{\circ} 31^{\prime} 05^{\prime \prime} \mathrm{W}$ \\
CA & Costa Azul-Bahia & $11^{\circ} 33^{\prime} 32^{\prime \prime} \mathrm{S} ; 47^{\circ} 47^{\prime} 06^{\prime \prime} \mathrm{W}$ \\
CJ & Itaporanga d'Ajuda-Sergipe & $11^{\circ} 06^{\prime} 40^{\prime \prime} \mathrm{S} ; 37^{\circ} 11^{\prime} 15^{\prime \prime} \mathrm{W}$ \\
$\mathrm{BI}$ & Barra do Itariri-Bahia & $11^{\circ} 48^{\prime} 39^{\prime \prime} \mathrm{S} ; 37^{\circ} 36^{\prime} 40^{\prime \prime} \mathrm{W}$ \\
$\mathrm{PT}$ & Indiaroba-Sergipe & $11^{\circ} 31^{\prime} 10^{\prime \prime} \mathrm{S} ; 37^{\circ} 30^{\prime} 47^{\prime \prime} \mathrm{W}$ \\
TC & Terra Caída-Sergipe & $0^{\circ} 46^{\prime} 31^{\prime \prime} \mathrm{S} ; 37^{\circ} 30^{\prime} 47^{\prime \prime} \mathrm{W}$ \\
\hline
\end{tabular}

Callogenesis was induced in nodal, internodal and foliar segments derivated from in vitro seedlings, cultivated in MS medium supplemented with $10 \mathrm{mg} \mathrm{L}^{-1}$ of 2,4-Dichlorophenoxyacetic acid (2,4-D) and $5.0 \mathrm{mg} \mathrm{L}^{-1}$ of benzylaminopurine (BA) (Adapted from: Prudente et al., 2016; Soares et al., 2011; Machado et al., 2016). After 60 days, the callus was extracted. 


\subsection{Preparation of Extracts}

Young leaves and callus obtained in vitro were dehydrated in ventilated oven (Marconi ${ }^{\circledR}$, MA035/1152) at $38-40{ }^{\circ} \mathrm{C}$ for $24 \mathrm{~h}$. Then, methyl alcohol solvent, $2 \mathrm{~g}$ of dry leaf in $20 \mathrm{~mL}$ of methanol $(\mathrm{MeOH})(\mathrm{Vetec} 囚)$ and 100 $\mathrm{mg}$ of dry callus in $10 \mathrm{~mL}$ of the same solvent were added and placed on ultrasound (Ultracleaner ${ }^{\mathrm{TM}} 1400$, Unique, Indaiatuba, São Paulo, Brazil) for $30 \mathrm{~min}$. After that, they were filtered and kept at room temperature until complete evaporation of the solvent.

\subsection{Chromatographic Conditions}

For chromatographic analysis in HPLC and UHPLC-High Performance/High Pressure Liquid Chromatography-chromatograph (Thermo Scientific ${ }^{\text {TM }}$ UltiMate $^{\text {TM }} 3000$, USA), $10 \mathrm{mg}$ of extract were dissolved in $10 \mathrm{~mL}$ of dimethyl sulfoxide-DMSO (Vetec ${ }^{\circledR}$ ). The mobile phase used was $\mathrm{MeOH}: \mathrm{H}_{2} \mathrm{O}$ in the proportion of 1:1 and vacuum filtered. The column used was the $\mathrm{C} 18(250 \mathrm{~mm} \times 4.6 \mathrm{~mm} ; 5 \mu \mathrm{m})$, the wavelength was $210 \mathrm{~nm}$, at room temperature, with a flow of $1 \mathrm{~mL} / \mathrm{min}$. The concentration of diluted extract was determined by interpolation of the area of each sample in a standard curve of rutin with concentration ranging from 10 to 100 ppm $(10,25,50,75,100 \mathrm{ppm})$. The rutin mass of the diluted extract was calculated by the formula: $\mathrm{m}$ Rutin $=\mathrm{CDE} \times \mathrm{VDE}$, where $\mathrm{m}$ Rutin $=$ rutin mass of the specimen, $\mathrm{CDE}=$ rutin concentration of the diluted extract and $\mathrm{VDE}=$ volume of diluted extract. Then, the plant mass ( $\mathrm{m}$ plant) required to produce $10 \mathrm{mg}$ of the extract was calculated through the formula: $\mathrm{m}$ plant $=\mathrm{m}$ extract/yield. The rutin content in the leaf was calculated by the method: Rutin content $(\%)=\mathrm{m}$ rutin/mplant. The calibration curve generated was validated by the analysis of a solution from the rutin pattern on concentration of $45 \mathrm{ppm}$. The concentration generated in the analysis was $43.97 \mathrm{ppm}$. Both in vivo leaves and callus were submitted to the same conditions of HPLC extraction and injection.

\subsection{Total Antioxidant Activity}

In vitro callus extracts and in vivo leaves were used. The Brand-Williams et al. (1995) method adapted by Rufino (2006) was applied. The absorbance readings were held after 180 to $220 \mathrm{~min}$ of spectrophotometer reaction of $515 \mathrm{~nm}$ wavelength (Thermo Scientific ${ }^{\mathrm{TM}}$ GENESYS 10S UV-Vis Spectrophotometer, USA). Absorbance decline of specimens related to loss of absorbance of the control (Ac) results in percentage of free radicals scavenging (\% FRS). The results were expressed in $\mathrm{g}$ of callus extract/g DPPH (2,2-diphenyl-1-picrilhydrazyl). The antioxidant capacity was expressed in required antioxidant concentration to reduce the original amount of free radicals in $50 \%\left(\mathrm{EC}_{50}\right)$.

Determination of the $\mathrm{EC}_{50}$, the sample concentration or pattern that causes $50 \%$ inhibition of the initial DPPH concentration, was obtained by linear regression of the plotted plot of the dilutions of the extracts $(40,20$ and 10 $\mu \mathrm{g} / \mathrm{ml}$ ). For plotting the points, the values of the means obtained from triplicates were used for each of the tests.

\subsection{Analysis of Genetic Diversity}

Young leaves from each genotype were used for DNA extraction (J. J. Doyle \& J. L. Doyle, 1987) with modifications and quantified in a spectrophotometer (Thermo Scientific NANODROP 2000c) at 260 and $280 \mathrm{~nm}$. The evaluation of the DNA quality was performed by agarose gel electrophoresis $1 \%(\mathrm{~m} / \mathrm{v})$, and visualized in Gel doc L-pix HE photo-documentation equipment (Loccus Biotecnologia, Brazil).

The specimens were diluted in $100 \mu \mathrm{L}$ of TE $(10 \mathrm{mM}$ Tris- $\mathrm{HCl}, \mathrm{pH} 8.0,1 \mathrm{mMEDTA})$ and stored at $-20{ }^{\circ} \mathrm{C}$ for subsequent use in ISSR (Inter-Simple Sequence Repeat) reactions. Eighteen ISSR (University of British Columbia, Vancouver, Canada) primers were used from (Table 2). 
Table 2. Synthesis initiators selected with their respective sequences and temperature

\begin{tabular}{lll}
\hline Primers & Sequence & Temperature $\left({ }^{\circ} \mathrm{C}\right)$ \\
\hline 807 & 5' AGA GAG AGA GAG AGA GT 3' & 47.0 \\
809 & 5' AGA GAG AGA GAG AGA GG 3' & 57.2 \\
810 & 5' GAG AGA GAG AGA GAG AT 3' & 54.8 \\
811 & 5' GAG AGA GAG AGA GAG AC 3' & 46.8 \\
812 & 5' GAG AGA GAG AGA GAG AA 3' & 54.8 \\
815 & 5' CTC TTC TCT CTC TCT CTG 3' & 47.6 \\
816 & 5' CAC ACA CAC ACA CAC AT 3' & 54.8 \\
817 & 5' CAC ACA CAC ACA CAC AA 3' & 54.8 \\
818 & 5' CAC ACA CAC ACA CAC AG 3' & 57.2 \\
823 & 5' TCT CTC TCT CTC TCT CC 3' & 57.2 \\
825 & 5' ACA CAC ACA CAC ACA CT 3' \\
826 & 5' ACA CAC ACA CAC ACA CC 3' & 54.8 \\
828 & 5' TGT GTG TGT GTG TGT GA 3' & 57.2 \\
834 & 5' AGA GAG AGA GAG AGY T 3' & 54.8 \\
848 & 5' CAC ACA CAC ACA CAC ARG 3' & 56.5 \\
855 & 5' ACA CAC ACA CAC ACY T 3' & 58.8 \\
856 & 5' ACA CAC ACA CAC ACA CYA 3' & 56.5 \\
888 & 5' BDB CAC ACA CAC ACA CA 3' & 56.5 \\
\hline
\end{tabular}

Regarding PCR tests, the total volume of the reaction was $20 \mu \mathrm{L}$, containing: $2 \mu \mathrm{L}$ of the genomic DNA solution; $1.0 \mu \mathrm{L}$ of each initiator along with a mix composed of $2 \mu \mathrm{L}$ of $10 \mathrm{X}$ PCR buffer; $0.4 \mu \mathrm{l}$ of dNTP $(10 \mathrm{mM}) ; 0.6 \mu \mathrm{L}$ of $\mathrm{MgCl}_{2}(50 \mathrm{mM}) ; 0.2 \mu \mathrm{L}$ of Taq DNA polymerase $(5 \mathrm{U} / \mu \mathrm{L}) \mathrm{Ludwig}{ }^{\circledR}$, and $12.8 \mu \mathrm{L}$ of ultrapure water.

For amplification of the reactions, the thermal cycler (Thermo Scientific ${ }^{\mathrm{TM}}$, MA, USA) was programmed in such a way that the samples were denatured at $95{ }^{\circ} \mathrm{C}$ for five minutes, followed by 45 cycles of amplification. Each cycle the specimens suffered a chain reaction of denaturation at $94{ }^{\circ} \mathrm{C}$ for one minute, girdling at various temperatures for 45 seconds and, finally, extension at $72{ }^{\circ} \mathrm{C}$ for two minutes (Soares et al., 2016).

In each microtube containing $20 \mu \mathrm{L}$ of amplified DNA, $2 \mu \mathrm{L}$ of specimen buffer $(0.01 \%$ bromophenol blue; $40 \%$ glycerol) were added. From this mixture, $17 \mu \mathrm{L}$ were arranged in channels of $2 \%$ agarose gel (dissolved in TBE 1X-Tris $89 \mathrm{mM}, 89 \mathrm{mM}$ boric acid, $2.5 \mathrm{mM}$ EDTA, pH 8.3) and subjected to horizontal electrophoresis in voltage of $200 \mathrm{~V}, 200 \mathrm{~mA}$, power of $100 \mathrm{~W}$ for approximately one hour and thirty-five minutes.

After electrophoresis, the gels were stained in ethidium bromide solution $(0.02 \mu \mathrm{L} / \mathrm{mL}$ of water $)$ for approximately $60 \mathrm{~min}$ for viewing under ultraviolet light. To measure the banding pattern, the $1 \mathrm{~Kb}$ molecular weight marker (Promega, Madison, South Dakota, USA) was used. The visualization of the gels was made in Loccus L-pix HE equipment (Loccus Biotecnologia, Brazil).

\subsection{Statistical Analysis}

To detect the differences between the treatments for total antioxidant activity and rutin content, were applied the variance analysis (ANOVA) and the Tukey's Test using the software SAS. For performing the grouping, the UPGMA (Unweighted Pair Group Method with Arithmetic Mean) method was used in the construction of phylogenetic relations and the dendrogram generated from the Jaccard similarity coefficient, obtained by the Ward method, with the electrophoretic profiles data coded to a binary matrix submitted to GENES program (Cruz, 2013) and the dendrogram by the statistical package STATISTICA 7.0, STATSOFT, Inc., 2004.

\section{Results}

\subsection{Identification of Phenolic Compounds in in vivo Leaves and Callus}

The generated calibration curve was validated by the analysis of a $45 \mathrm{ppm}$ routine standard solution. The concentration generated in the analysis was $43.97 \mathrm{ppm}$, which represents a $2 \%$ error of the measured value in relation to the expected value. The concentration of the diluted extract was determined by interpolating the area of each sample on a routine standard curve showing different values for concentration of the accessions to rutin mass and content in in vivo leaves (Table 3). 
Table 3. Chromatographic analysis of rutin mass (mg) and content (\%) in leaf (in vivo) extracts of Hancornia speciosa. Accessions: AB (Água Boa), BI (Barra do Itariri), CA (Costa Azul), CJ (Itaporanga), TC (Terra Caída) and PT (Pontal)

\begin{tabular}{lllll}
\hline Accessions & Rutin Concentration $(\mathrm{mg} / \mathrm{L})$ & M Rutin $(\mathrm{mg})$ & M plant $(\mathrm{mg})$ & Content $(\%)$ \\
\hline AB & $55.20 \pm 6.95 \mathrm{ab}$ & $0.55 \pm 0.07 \mathrm{ab}$ & $75.81 \pm 7.35 \mathrm{a}$ & $0.73 \pm 0.13 \mathrm{a}$ \\
BI & $64.26 \pm 11.22 \mathrm{a}$ & $0.64 \pm 0.11 \mathrm{a}$ & $93.17 \pm 7.85 \mathrm{a}$ & $0.68 \pm 0.07 \mathrm{a}$ \\
CA & $59.27 \pm 11.04 \mathrm{ab}$ & $0.59 \pm 0.11 \mathrm{ab}$ & $83.40 \pm 10.93 \mathrm{a}$ & $0.71 \pm 0.09 \mathrm{a}$ \\
CJ & $67.26 \pm 13.14 \mathrm{a}$ & $0.67 \pm 0.13 \mathrm{a}$ & $89.12 \pm 14.81 \mathrm{a}$ & $0.78 \pm 0.25 \mathrm{a}$ \\
PT & $35.56 \pm 7.67 \mathrm{~b}$ & $0.35 \pm 0.08 \mathrm{~b}$ & $79.41 \pm 10.52 \mathrm{a}$ & $0.45 \pm 0.16 \mathrm{a}$ \\
TC & $42.75 \pm 5.76 \mathrm{ab}$ & $0.42 \pm 0.06 \mathrm{ab}$ & $72.01 \pm 4.55 \mathrm{a}$ & $0.59 \pm 0.07 \mathrm{a}$ \\
VC $(\%)$ & 17.35 & & & \\
\hline
\end{tabular}

Note. * Same lower case letters in a column do not differ significantly by the Tukey test $(\mathrm{p}<0.05)$.

The BI and CJ accessions reached greater rutin concentration (64.26 and $67.26 \mathrm{mg}$ of rutin/L of extract) among the accessions studied. Differences in rutin concentration between accessions can be related to the phenolic compounds of plants. There was no detection of rutin peaks in callus obtained from in vitro culture of leaf segments.

\subsection{Antioxidant Activity}

There was a significant effect of the mangaba tree accessions on the values obtained for the $\mathrm{EC}_{50}$ in in vivo leaves and in vitro callus $(P<0.05)$. The $\mathrm{EC}_{50}$ was calculated from the $29.3 \mu \mathrm{mol} / \mathrm{mL}$ concentration of $\mathrm{DPPH}$ and methanol, using $50 \%$ of the absorbance of that dilution. For the antioxidant activity of the in vivo accessions from leaf extracts, the $\mathrm{BI}$ and $\mathrm{CA}$ obtained higher capacity in capturing the free radicals $\left(\mathrm{EC}_{50}=110.09\right.$ and $176.03 \mathrm{~g}$ dry extract/g DPPH) when compared with the others (Figure 1). The presence of rutin in these accessions (BI and CA) was identified and quantified with approximate values of $51.6 \mathrm{mg}$ of rutin/L of extract and $52.9 \mathrm{mg}$ of rutin/L of extract, respectively.

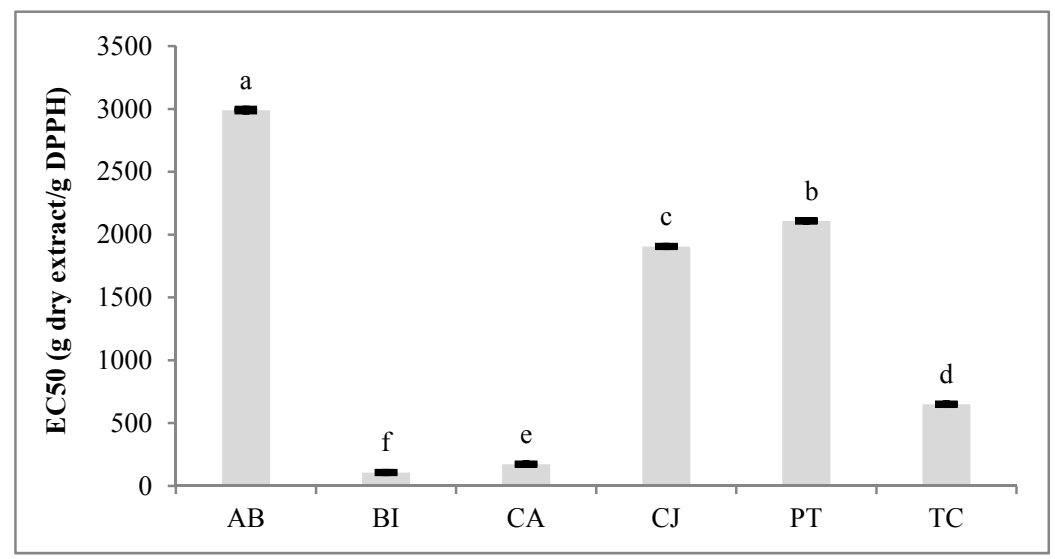

Figure 1. Antioxidant activity by DPPH method in in vivo leaf of six mangaba accessions from the Mangaba Germplasm Bank. Embrapa Coastal Tablelands, Sergipe, Brazil. AB (Água Boa), BI (Barra do Itariri), CA (Costa Azul), CAJU (Itaporanga), TC (Terra Caída) and PT (Pontal). Same letters do not differ significantly by the Tukey test $(\mathrm{p}<0.05)$

Since no previously published articles determine the antioxidant activity using DPPH method for mangaba leaves and in vitro callus, it is only possible to compare the results related by Rufino et al. (2010) in mangaba fruits with $\mathrm{EC}_{50}$ of $3345 \mathrm{~g} / \mathrm{g}$ DPPH. Thereby, the antioxidant activity of the callus extracts expresses the ability of eliminating free radicals in DPPH tests, which can be correlated with the total amount of compounds present in callus. Therefore, in the same study the values of other tropical fruits such as Carnaúba (Copernicia prunifera) and Cajá (Spondias mombin) obtained higher Ec50, that is, with lower antioxidant capacity. Thus the 
establishment of antioxidant activity level will assist in future studies comparing with different parts of the plant and performing other chemical analyzes is relevant.

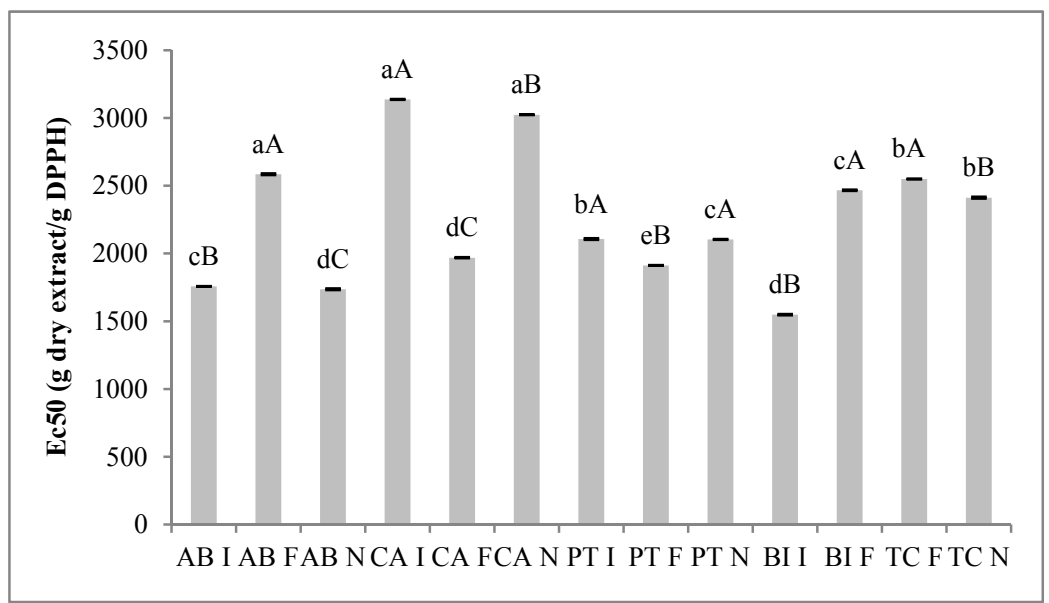

Figure 2. Antioxidant activity by DPPH method of in vitro callusof six mangaba accessions from the Mangaba Germplasm Bank. Embrapa Coastal Tablelands, Sergipe, Brazil. AB (Água Boa), BI (Barra do Itariri), CA (Costa Azul), CJ (Itaporanga), TC (Terra Caída) and PT (Pontal). (I: Internodal; F: Leaves; N: Nodal). Same lower case letters (for accessions) and capital letters (explant types) do not differ significantly by the Tukey test $(\mathrm{p}<0.05)$

The highest values for $\mathrm{EC}_{50}(3000 \mathrm{~g}$ dry extract/g DPPH) were observed in callus of the CA accession coming from nodal and internodal segments (Figure 2), suggesting the lower antioxidant capacity between the accessions. Extracts from $\mathrm{AB}$ (nodal and internodal segments) and BI (internodal segment) accessions presented lower antioxidant activity (1554.81 $\mathrm{g}$ of dry extract/g of DPPH) when compared to the others accessions.

According to Reynertson et al. (2005) the intensity of antioxidant activity can be measured from the effective concentration $\left(\mathrm{EC}_{50}\right)$, using the results of antioxidant activity of dilutions in series. $\mathrm{EC}_{50}$ is the concentration of extract needed to reduce $50 \%$ of radical $\mathrm{DPPH}$ and the lower the value of $\mathrm{EC}_{50}$ the greater the antioxidant activity. Extracts with $\mathrm{EC}_{50}$ below $50 \mu \mathrm{g} \mathrm{m} / \mathrm{L}$ indicate elevated activity, from $50 \mu \mathrm{g} / \mathrm{mL}$ to $100 \mu \mathrm{g} / \mathrm{mL}$ indicate moderate activity, from $100 \mu \mathrm{g} / \mathrm{mL}$ to $200 \mu \mathrm{g} / \mathrm{mLactivity}$ and above $200 \mu \mathrm{g} / \mathrm{mL}$ are considered inactive (Reynertson et al., 2005). Despite the high value found, it was observed the change in the coloration of the solutions with DPPH and extract from 60 minutes, this change in color indicates the occurrence of antioxidant activity.

Callus of Harpagophytum procumbens Burch. achieved higher $\mathrm{EC}_{50}(46.7 \mu \mathrm{g} / \mathrm{mL})$ on $\mathrm{MS}$ medium with $0.2 \mathrm{mg} / \mathrm{L}$ of NAA (naftalen acetic acid) and $1 \mathrm{mg} / \mathrm{L}$ BA (Grabkowsa et al., 2016). On the other hand, Giri et al. (2012) reported that on callus of Habenaria edgeworthii the total phenolic content varied significantly in callus grown on BA, and ranged from 10.33 to $14.30 \mathrm{mg}$ gallic acid equivalent (GAE)/g dry weight (DW) and antioxidant activity showed maximum activity in callus grown on $3.0 \mu \mathrm{M}$ BA containing medium.

In studies with in vitro Passiflora pofliicallus, Simão et al. (2016) observed greater antioxidant activity in ethanolic extract on primary and secondary roots. Fazal et al. (2016) obtained no significant differences for the antioxidant activity in $P$. vulgaris callus. The difference between the amount and growth regulators used on the induction of callus modify the antioxidant activity (Bonfil et al., 2014). Another factor to be considered is the presence of chemical constituents in the extract, those responsible for antioxidant activity (Sadeghi et al., 2015).

It was not possible to determine the antioxidant activity in the CJ accession due to in vitro callus formation, there was oxidation of the tissue, requiring adjustment of protocol of callus induction. This result reinforces the genotype-dependence of Hancornia speciosa Gomes to callus formation. According to reports by Benderradji et al. (2012), genetic factors are considered one of the main contributors to the in vitro response. Thereby, there is difference in the callus production and plant regeneration, depending on the genotype and source of the explants (Ganesha et al., 2006). 


\subsection{Molecular Analysis}

The 17 ISSR initiators resulted in 39 fragments, of which 24 were polymorphic (52.07\%) (Table 4). The allogamy of mangaba tree and its self-incompatibility makes the plants derived from highly divergent seeds among themselves and in relation to the mother plant (Vieira Neto, 2002; Darrault \& Schlindwein, 2006).

Table 4. Number of bands formed using different primers in mangaba accessions.

\begin{tabular}{llll}
\hline Primers & Number of fragments & Number of polymorphic fragments & \% of Genetic similarity \\
\hline 811 & 2 & 0 & 0 \\
807 & 2 & 2 & 100 \\
815 & 3 & 1 & 33 \\
816 & 1 & 0 & 0 \\
817 & 4 & 3 & 75 \\
855 & 3 & 2 & 66 \\
823 & 5 & 4 & 80 \\
825 & 4 & 1 & 25 \\
826 & 3 & 3 & 100 \\
888 & 2 & 2 & 100 \\
856 & 2 & 1 & 50 \\
810 & 2 & 0 & 0 \\
816 & 1 & 0 & 0 \\
848 & 5 & 5 & 100 \\
\hline Total & 39 & 24 & 52.07 \\
\hline
\end{tabular}

Therefore, inside the germplasm bank progenies hybridization may occur due to natural pollinator agents. Soares et al. (2016) carried out the test with 155 mangaba individuals of natural species from Sergipe, concluding $100 \%$ of polymorphism presenting high genetic variability among populations. The rate of genetic similarity of this study was considered low when compared with the study on natural species, the fact of the matrices belonging to the $\mathrm{BAG}$, factors such as geographical proximity of the accessions and the position of the matrices in the experimental field, interfere in genetic diversity between matrix/progeny. Therefore, when comparing the matrices and the progenies of our study, we concluded that the genetic similarity was maintained in all accessions to seeds germinated in vitro.

In general, the genetic distance among the studied accessions was large, since there is a genotypic and phenotype difference between accessions. However, the genetic diversity between matrix and progeny was low. In CA, CJ and PT accessions we observed higher values for genetic distance between the matrix and progeny (Figure 3). 


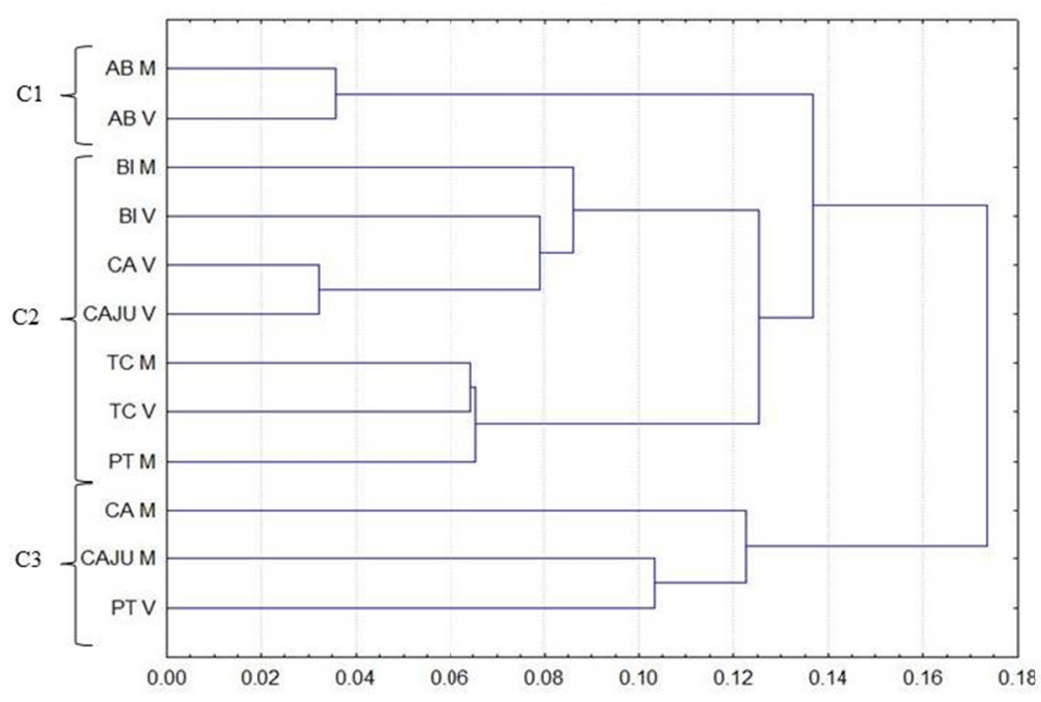

Figure 3. Dendrogram generated from the Jaccard similarity coefficient, obtained by the Ward method, using 14 primers through the ISSR technique among 12 mangaba individuals belonging to the Mangaba Germplasm Bank of Embrapa Coastal. Accessions: AB (Água Boa), BI (Barra do Itariri), CA (Costa Azul), CAJU (Itaporanga), TC

(Terra Caída) and PT (Pontal). (M: Matrix; V: in vitro)

We highlight the CA accession, which had greater genetic distance between matrix/progeny, and EC50 data were different between leaf and callus.

\section{Discussions}

\subsection{Identification of Phenolic Compounds in in vivo Leaves and Callogenesis}

Callus induced from Gynochthdes umbellata leaves, obtained higher concentration of anthraquinone (18.18 \pm 0.58$)$ on MS medium supplemented by $1 \mathrm{mg} / \mathrm{L}$ of 2,4-D after 60 days of cultivation (Anjusha \& Gangaprasa, 2017).

According to Chavan et al. (2015), different concentrations of auxins and cytokinins change in the quantification of the studied compound in in vitro callus cultures. In the study conducted by Khattab et al. (2014), using of phytoregulators in callogenesis of Pilosocereus robinii, were detected the minimum concentrations of the malic acid phenolic compound. Other factors may be considered on the in vitro production of secondarymetabolitessuch as abiotic factors, temperature, humidity, light, water supply, minerals and $\mathrm{CO}_{2}$. They influence plant growth and directly affect the biochemical ways (Akula \& Ravishankar, 2011), and the genetic factors interfere in the synthesis of these compounds (Bai et al., 2017). Fazal et al. (2016) suggest that the use of LED lamps is a promising approach to the antioxidant secondary metabolites production in Phaseolus vulgaris callus cultures.

Rutin was not decteted in extract from callus obtained from leaf explants. Similar results of absence of flavonoids were obtained by Szopa et al. (2016), in in vitrocallus of Schisandra chinensis (Turcz.), popularly known as Chinese Magnolia. In opposite, a study conducted by Castro et al. (2016), showed the potential of in vitro Murici-do-cerrado (Byrsonomia verbascifolia Rich.) callus as a new source of total phenolic compounds. Changes in injection or extraction protocol, as well as in the concentrations and types of growth regulators, are essential for optimizing the in vitro rutin production from callus.

\subsection{Antioxidant Activity}

The values of $\mathrm{EC}_{50}$ obtained in this study are higher than those observed by Damiano et al. (2017) with methanolic extract of Ziziphus jujuba Mill. leaves with results of $\mathrm{EC}_{50}$ was $25 \mu \mathrm{g} / \mathrm{mL}$, concluding higher antioxidant activity when compared to the results obtained in this study. The DPPH analysis in extract of Olea europaea leaves held by Difonzo et al. (2017) obtained antioxidant potential, and in the chromatographic profile the rutin compound was identified. Torres-Rêgo et al. (2016) observed the anti-inflammatory effect of rutin and chlorogenic acid extracted from mangaba fruits in animal models. Thus, these results corroborate our study, due to the identification of different rutin concentrations among accessions on in vivo mangaba leaves, concluding that this chemical compound is related to all analyses carried out in this research. 
Plants frequently cope up with the rapid fluctuations and adversity of environmental conditions because of their intrinsic metabolic capabilities (Simontacchi et al., 2015). Variations in the outside environment could put the plant metabolism out of homeostasis (Foyer \& Noctor, 2005), and create necessity for the plant to harbor some advanced genetic and metabolic mechanisms within its cellular system (Apel \& Hirt, 2004; Gill \& Tuteja, 2010). Plants possess an array of protective mechanisms acquired during the course of evolution to combat adverse environmental situations (Yolcu et al., 2016).

\subsection{Molecular Analysis}

The similarity between accessions of nearby regions such as Sergipe and Bahia can be explained by the movement of genes within plant populations that are conditioned by the degree of genetic compatibility between the individuals of the population (Silva et al., 2011). Khattab et al. (2014) used the ISSR-PCR technique to prove the genetic polymorphism of the explants submitted to MS medium supplemented with TDZ and 2,4-D in Pilosocereus robinii, determining that abiotic factors may interfere with DNA.

There was low genetic divergence between the matrix and the progenies, with the exception of PT, CA and CJ, in which the distance was approximately 0.06 . This fact suggests that the alogamy of the matrices in the Caju reserve can cause a greater genetic distance between the progeny and the mother plant. The results of genetic divergence corroborate with the results obtained by Cheruvathur et al. (2012), where the analysis of ISSR data in nine plants regenerated in vitro from $R$. nasutus callogenesis and the mother plant, the use of 12 ISSR markers indicated low genetic variability. In a study with ISSR markers in plants regenerated in vitro from the callogenesis, Perera et al. (2015) concluded that these are useful in detecting polymorphisms in Miscanthus $\times$ Giganteus and can be used for generation and screening of mutants leading to the development of new cultivars.

The divergence data were compared with previous successful studies in individuals of the native population of Hancornia speciosa Gomes (Santos et al., 2017; Silva et al., 2017; Soares et al., 2016; Amorim et al., 2015; Costa et al., 2015; Jimenez et al., 2015; Silva et al., 2013) and BAGs (Silva et al., 2011; Costa et al., 2011; Luz, 2016; Vitória, 2017), with the use of molecular markers.

In the present study, the use of molecular markers has been used in a number of studies, including the use of molecular markers (Silva et al., 2011). The results of genetic divergence corroborate the results obtained by Cheruvathur et al. (2012), where the analysis of ISSR data in nine plants regenerated in vitro from callogenesis of $R$. nasutus and mother plant, the use of 12 ISSR markers indicated low genetic variability. The combination of phytochemical studies and genetic similarity favors the identification of more divergent individuals with characteristics of interest. The results will collaborate on the conservation strategies of BGMangaba and future breeding programs.

\section{Conclusions}

The rutin concentrations in the $\mathrm{BI}$ and $\mathrm{CJ}$ accessions were 64.26 and $67.26 \mathrm{mg} / \mathrm{L}$ of extract. The antioxidant activity of the in vivo accessions from $\mathrm{BI}$ and $\mathrm{CA}$ leaves extracts was higher $\left(\mathrm{EC}_{50}=110.09\right.$ and $176.03 \mathrm{~g}$ of dry extract/g of DPPH). The antioxidant activity of the in vitro accessions from different explant extracts showed lower antioxidant capacity. Rutin is detected in different amounts of in vivo leaf extract. However, the rutin is not detected in extracts from in vitro callus of mangaba tree. DPPH concentration is superior in extracts from in vitro callus, with the in vitro CA accession (internodal and nodal). There is low diversity among the evaluated mangaba accessions; however, there is high genetic similarity between matrices and their progenies. The CA accession groups itself in isolation from others and $\mathrm{EC}_{50}$ concentrations differentiated between leaf and callus are obtained.

\section{References}

Akula, R., \& Ravishankar, G. A. (2011). Influence of abiotic stress signals on secondary metabolites in plants. Plant Signaling \& Behavior, 6, 1720-1731. https://doi.org/10.4161/ psb.6.11.17613

Amorim, J. A., Mata, L. R., Lédo, A. S., Azevedo, V. C., Silva, A. V. C. (2015). Diversity and genetic structure of mangaba remnants in states of northeastern Brazil. Genetics and Molecular Research, 14(1), 823-33. https://doi.org/10.4238/2015

Anjusha, S., \& Gangaprasad, A. (2017). Callus culture and in vitro production of anthraquinone in Gynochthodes umbellata (L.) Razafim. \& B. Bremer (Rubiaceae). Industrial Crops Production, 95, 608-614. https://doi.org/10.1016/j.indcrop.2016.11.021

Apel, K., \& Hirt, H. (2004). Reactive oxygen species: Metabolism, oxidative stress, and signal transduction. Annual Review of Plant Biology, 55, 373-399. https://doi.org/10.1146/annurev.arplant.55.031903.141701 
Bai, Y., Xu, Y., Wang, B., Li, S., Guo, F., Hua, H., .. Yu, Z. (2017). Comparison of phenolic compounds, antioxidant and antidiabetic activities between selected edible beans and their different growth periods leaves. Journal of Functional Foods, 35, 694-702. https://doi.org/10.1016/j.jff.2017.06.036

Benderradji, L., Brini, F. A., Kellou, K., Ykhlef, N., Djekoun, A., Masmoudi, K., \& Bouzerzour, H. (2012). Callus Induction, Proliferation, and Plantlets Regeneration of Two Bread Wheat (Triticum aestivum L.) Genotypes under Saline and Heat Stress Conditions. International Scholarly Research Notices, Article ID 367851. https://doi.org/10.5402/2012/367851

Bonfil, B. P. M., Cruz-Hernandez, A., Lopez-Laredo, A. R., Trejo-Tapia, G., \& Trejo-Espino, J. L. (2014). Effects of culture medium and auxins on growth of adventitious root cultures of Cuphea aequipetala Cav. and their ability to produce antioxidant compounds. Plant Cell Tissue Organ Culture, 118, 401-408. https://doi.org/ 10.1007/s11240-014-0492-6

Borges, A., Rosa, M. S., Recchia, G. H., Silva, J. R. Q., Bressan, E. A., \& Veasey, E. A. (2009). CTAB methods for extraction of sweetpotato for microsatellite analysis. Scientia Agrícola, 66(4), 529-534. https://doi.org/10.1590/S0103-90162009000400015

Brand-Wiliams, W., Cuvelier, M. E., \& Berset, C. (1995). Use of a free radical method to evaluate antioxidant activity. Food Science and Technology, 28, 25-30. https://doi.org/10.1016/S0023-6438(95)80008-5

Castro, A. H. F., Braga, K. Q., Sousa, F. M., Coimbra, M. C., \& Chagas, R. C. R. (2016). Callus induction and bioactive phenolic compounds production from Byrsonima verbascifolia (L.) DC. (Malpighiaceae). Revista Ciência Agronômica, 47(1), 143-151. https://doi.org/10.5935/1806-6690.20160017

Castro, H. G. de, Silva, D. J. H. da, Oliveira, L. O. de, Ferreira, F. A., Sakiyama, N. S., Barbosa, L. C. de A., \& Júnior, J. I. R. (2004). Diversidade genética entre acessos de mentrasto avaliados por características botânico-agronômicas, moleculares e fitoquímicas. Revista Ceres, 51, 227-241.

Chavan, J. J., Ghadage, D. M., Bhoite, A. S., \& Umdale, S. D. (2015). Micropropagation, molecular profiling and RP-HPLC determination of mangiferin across various regeneration stages of Saptarangi (Salaciachinensis L.). Industrial Crops Production, 76, 1123-1132. https://doi.org/10.1016/j.indcrop.2015. 08.028

Cheruvathur, M. K., Sivub, A. R., Pradeep, N. S., \& Thomas, D. T. (2012). Shoot organogenesis from leaf callus and ISSR assessment for their identification of clonal fidelity in Rhinacanthus nasutus (L.) Kurz., a potent anticancerous ethnomedicinal plant. Industrial Crops Production, 40, 122-128. https://doi.org/10.1016/ j.indcrop.2012.02.043

Costa, T. S., Silva, A. V. C. da, Lédo, A. S., Santos, A. R. F., \& Silva Júnior, J. F. da. (2011). Diversidade genética de acessos do banco de germoplasma de mangaba em Sergipe. PesquisaAgropecuária Brasileira, 46. https://doi.org/10.5039/agraria.v6i4a943

Cruz, C. D. (2013). GENES - A software package for analysis in experimental statistics and quantitative genetics. Acta Scientiarum, 35(3), 271-276.

Cruz, C. D., Regazzi, A. J., \& Carneiro, P. C. S. (2012). Modelos biométricos aplicados ao melhoramento Genético (2nd ed.). UFV, Viçosa, Brazil.

Damiano, S., Forino, M., de, A., Vitali, L. A., Lupidi, G., \& Taglialatela-Scafati, O. (2017). Antioxidant and antibiofilm activities of secondary metabolites from Ziziphus jujuba leaves used for infusion preparation. Food Chemistry, 230, 24-29. https://doi.org/10.1016/j.foodchem.2017.02.141

Darrault, R. O., \& Schlindwein, C. (2006). Polinização. In J. F. Silva Junior, \&A. S. Ledo (Eds.), A cultura da mangabeira (pp. 43-56). Aracaju: Embrapa Tabuleiros Costeiros.

Difonzo, G., Russo, A., Trani, A., Paradiso, V. M., Ranieri, M., Pasqualone, A., ... Caponio, F. (2017). Green extracts from Coratina olive cultivar leaves: Antioxidant characterization and biological activity. Journal of Functional Foods, 31, 63-70. https://doi.org/10.1016/j.jff.2017.01.039

Doyle, J. J., \& Doyle, J. L. (1990). Isolation of plant DNA from fresh tissue. Focus, 12(1), 13-15.

Fazal, H., Abbasi, B. H., Ahmad, N., Ali, S. S., Akbar, F., \& Kanwal, F. (2016). Correlation of different spectral lights with biomass accumulation and production of antioxidant secondary metabolites in callus cultures of medicinally important Prunella vulgaris L. Journal of Photochemistry \& Photobiology, B: Biology, 159, 1-7. https://doi.org/10.1016/j.jphotobiol.2016.03.008 
Ferreira, D. F. (2014). Sisvar: A Guide for its Bootstrap procedures in multiple comparisons. Ciência. Agrotécnica, 38(2), 109-112. https://doi.org/10.1590/S1413-70542014000200001

Ferreira, H. C., Serra, C. P., Endringer, D. C., Lemos, V. S., Braga, F. C., \& Cortes, S. F. (2007). Endothelium-dependent vasodilation induced by Hancornia speciosa in rat superior mesenteric artery. Phytomedicine, 14, 473-478. https://doi.org/10.1016/j.phymed.2006.11.008

Foyer, C. H., \& Noctor, G. (2005). Oxidant and antioxidant signalling in plants: A re-evaluation of the concept of oxidative stress in a physiological context. Plant Cell Environment, 28, 1056-1071. https://doi.org/10.1111/ j.1365-3040.2005.01327.x

Fu, Z., Tu, Z., Zhang, L., Wang, H., Wen, Q., \& Huang, T. (2016). Antioxid ant activities and polyphenols of sweet potato (Ipomoea batatas L.) leaves extracted with solvents of various polarities. Food Bioscience, 15, 11-18. https://doi.org/10.1016/j.fbio.2016.04.004

Ganeshan, S., Baga, M., Harwey, B. L., Rossnagel, B. G., Scoles, G. J., \& Chibbar, R. N. (2003). Production of multiple $\mathrm{s}$ hoots from thiadiazuron-treated mature embryos and leaf-base/apical meristems of barley (Hordeum vulgare L.). Plant Cell TissueOrgan Culture, 73, 57-64. https://doi.org/10.1016/j.sjbs. 2013.02.008

Gill, S. S., \& Tuteja, N. (2010). Reactive oxygen species and antioxidant machinery in abiotic stress tolerance in crop plants. Plant Physiology Biochemistry, 48, 909-930. https://doi.org/10.1016/j.plaphy.2010.08.016

Giri, L., Dhyani, P., Rawat, S., Bhatt, I. D., Nandi, S. K., Rawal, R. S., \& Pande, V. (2012). In vitro production of phenolic compounds and antioxidant activity in callus suspension cultures of Habenaria edgeworthii: A rare Himalayan medicinal orchid. Industrial Crops and Products, 39, 1-6. https://doi.org/10.1016/j.indcrop. 2012.01 .024

Grąbkowska, R., Matkowski, A., Grzegorczyk-Karolak, I., \& Wysokińska, H. (2016). Callus cultures of Harpagophytum procumbens (Burch.) DC. Ex Meisn., production of secondary metabolites and antioxidant activity. South African Journal of Botany, 103, 41048. https://doi.org/10.1016/j.sajb.2015.08.012

IBGE (Brazilian Institute of Geography and Statistics). (2016). Retrieved January 10, 2018, from https://agenciadenoticias.ibge.gov.br/agencia-noticias/2013-agencia-de-noticias/releases/16981-pevs-2016-p roducao-da-silvicultura-e-da-extracao-vegetal-alcanca-r-18-5-bilhoes.html

Khattab, S., Sherif, F. E., El-Garhy, H. A., Ahmed, S., \& Ibrahim, A. (2014). Genetic and phytochemical analysis of the in vitro regenerated Pilosocereus robinii by ISSR, SDS-PAGE and HPLC. Gene, 533, 313-321. https://doi.org/10.1016/j.gene.2013.09.026

Luz, G. A. (2016). Diversidade genética em acessos de mangaba do banco de germoplasma da Embrapa Meio-Norte (56f. Dissertação, Mestrado em Genética e Melhoramento, Universidade Federal do Piauí, Teresina, Brazil).

Machado, C. A., Oliveira, L. A. R., Oliveira, A. C. A., Cardoso, M. N., \& Ledo, A. S. (2016). Efeito de fitorregulares na indução de calos de Hancornia speciosa Gomes. VI Seminário de Iniciação à Pesquisa Científica e Pós-graduação da Embrapa Tabuleiros Costeiros.

Morais, T. P., Luz, J. M. Q., Silva, S. M., Resende, R. F., \& Silva, A. S. (2012). Aplicações da cultura de tecidos em plantas medicinais. Revista Brasileira de Plantas Medicinais, 14(1), 110-121. https://doi.org/10.1590/ S1516-05722012000100016

Oliveira, K. S., Freire, F. A. M., \& Aloufa, M. A. I. (2016). Efeito de 6-benzilaminopurina e ácido naftalenoacético sobre propagação in vitro de Hancornia speciosa Gomes. Revista Floresta, 46, $335-342$. https://doi.org/10.5380/rf.v46i3.43993

Perera, D., Barnes, B. D. J., Baldwinc, B. S., \& Reichert, D. N. A. (2015). Mutagenesis of in vitro cultures of Miscanthus $\times$ giganteus cultivar Freedom and detecting polymorphisms of regenerated plants using ISSR markers. Industrial Crops Products, 65, 110-116. https://doi.org/10.1016/j.indcrop.2014.12.005

Perez-Vizcaino, F., Duarte, J., Jimenez, R., Santos-Buelga, C., \& Osuna, A. (2009). Antihypertensive effects of the flavonoid quercetin. Pharmacology, 61, 67-75. https://doi.org/10.1016/S1734-1140(09)70008-8

Prudente, D. O., Paiva, R., Nery, F. C., Máximo, W. P., \& Silva L. C. (2016). Organogênese indireta in vitro de Hancornia speciosa Gomes. Bioscience Journal, 32(3), 721-729. https://doi.org/10.14393/BJ-v32n3a 2016-30381 
Reynertson, K. A., Basile, M. J., \& Kennelly, E. J. (2005). Antioxidant potential of seven myrtaceous fruits. Ethnobotany Research \& Applications, 3, 25-35. https://doi.org/10.17348/era.3.0.25-36

Rufino, M. S. M., Alves, R. E., Brito, E. S., Morais, S. M., Sampaio, C. G., Pérez-Jiménez, J., \& Saura-Calixto, F. D. (2007). Metodologia Científica: Determinação da Atividade Antioxidante Total em frutas pela captura do Radical Livre DPPH. Comunicado Técnico, Embrapa.

Rufino, M. S. M., Alves, R. E., Brito, E. S., Perez-Jimenez, J., Jaura-Calizto, F., \& Mancini-Filho, J. (2010). Bioactive compounds and antioxidant capacities of 18 non-traditional tropical fruits from Brazil. Food Chemistry, 121, 996-1002. https://doi.org/10.1016/j.foodchem.2010.01.037

Rufino, M. S. M., Fernandes, F. A. N., Alves, R. E., \& Brito, E. S. (2009). Free radical-scavenging behaviour of some north-east Brazilian fruits in a DPPH system. Food Chemistry, 114, 693-695. https://oi.org/10.1016/ j.foodchem.2008.09.098

Sadeghi, Z., Valizadeh, J., Shermeh, O. A., \& Akaberi, M. (2015). Antioxidant activity and total phenolic content of Boerhavia elegans (choisy) grown in Baluchestan, Iran. Avicenna Journal of Phytomedicine, 5(1), 1-9.

Sánchez-Moreno, C., Larrauri, J. A., \& Saura-Calixto, F. (1998). A procedure to measure the antiradical efficiency of polyphenols. Journal of the Science of Food and Agriculture, 76, 270-276. https://doi.org/ 10.1002/(SICI)1097-0010(199802)76:2<270::AID-JSFA945>3.0.CO,2-9

Santos, P. S., Freitas, L. S., Santana, J. G. S., Muniz, E. N., Rabbani, A. R. C., \& Silva, A. V. C. (2017). Genetic diversity and the quality of Mangabeira tree fruits (Hancornia speciosa Gomes-Apocynaceae), a native species from Brazil. Scientia Horticulturae, 226, 372-378. https://doi.org/10.1016/j.scienta.2017.09.008

Serra, C. P., Côrtes, S. F., Lombardi, J. A., Bragade Oliveira, A., \& Braga, F. C. (2005). Validation of a colorimetric assay for the in vitro screening of inhibitors of angiotensin-converting enzyme (ACE) from plant extracts. Phytomedicine, 12, 424-432. https://doi.org/10.1016/j.phymed.2004.07.002

Silva, A. V. C., Santos, A. R. F., Wickert, E., Silva Júnior, J. F., \& Costa, T. S. (2011). Divergência genética entre acessos de mangabeira (Hancornia speciosa Gomes). Revista Brasileira de Ciências Agrárias, 6(4), 572-578. https://doi.org/10.5039/agraria.v6i4a943

Silva, A. V. C., Soares, A. N. R., Ledo, A. S., Costa, T. S., Almeida, C. S., Amorim, J. A. E., ... Vitória, M. F. (2017). Uses and technological prospects for the mangaba, a native fruit of Brazil. African Journal of Biotechnology, 16(7), 302-311. https://doi.org/10.5897/AJB2016.15786

Simão, M. J., Fonseca, E., Garcia, R., Mansur, E., \& Pacheco, G. (2016). Effects of auxins and different culture systems on the adventitious root development of Passiflora pohlii Mast. and their ability to produce antioxidant compounds. Plant Cell Tissue Organ Culture, 124, 419-430. https://doi.org/10.1007/s11240015-0904-2

Simontacchi, M., Galatro, A., Ramos-Artuso, F., \& Santa-Maria, G. E. (2015). Plant survival in a changing environment: The role of nitric oxide in plant responses to abiotic stress. Frontries Plant Science, 6, 977. https://doi.org/10.3389/fpls.2015.00977

Soares, A. N. R., Vitória, M. F., Nascimento, A. L. S., Ledo, A. S., Rabbani, A. R. C., \& Silva, A. V. C. (2016). Genetic diversity in natural populations of mangaba in Sergipe, the largest producer State in Brazil. Genetic Molecular Research, 15, 1-12. https://doi.org/10.4238/gmr.15038624

Soares, F. P., Paiva, R., Alvarenga, A. A., Nery, F. C., Vargas, D. P., \& Silva, D. R. G. (2011). Taxa de multiplicação e efeito residual de diferentes fontes de citocinina no cultivo in vitro de Hancornia speciosa Gomes. Ciência Agrotécnica, 35(1), 152-157. https://doi.org/10.1590/S1413-70542011000100019

Sousa, R. M. F., Lira, C. S., Rodrigues, A. O., Morais, S. A. L., Queiroz, C. R. A. A., Chang, R., ... Oliveira, A. (2014). A atividade antioxidante de extratos de folhas de Ora-Pronóbis (Pereskia aculeata Mill.) usando métodos espectrofotométricos e voltamétricos in vitro. Bioscience Journal, 30(1), 448-457.

Statsoft, Inc. (2004). STATISTICA (Version 7). Retrieved from http://www.statsoft.com

Szopa, A., Kokotkiewecz, A., Bernarz, M., Luczkiewicz, M., \& Ekiert, H. (2016). Studies on the accumulation of phenolic acids and flavonoids in different in vitro culture systems of Schisandra chinensis (Turcz.) Baill. using a DAD-HPLC method. Phytochemistry Letters, 1269, 1-8. https://doi.org/10.1016/j.phytol.2016. 10.016

Torres-Rêgo, M., Furtado, A. A., Bitencourt, M. A. O., Lima, M. C. J. S., Rafael Caetano Andrade, L. C., Eduardo Pereira de Azevedo, E. P. A., ... Fernandes-Pedrosa, M. F. (2016). Anti-inflammatory activity of 
aqueous extract and bioactive compounds identified from the fruits of Hancornia speciosa Gomes (Apocynaceae). BMC Complementary and Alternative Medicine, 16, 275. https://doi.org/10.1186/s12906016-1259-x

Vieira Neto, R. D. (2002). Mangaba. Frutiferas potenciais para tabuleiros costeiros e baixadas litorâneas. Embrapa Tabuleiros Costeiros, Aracaju.

Vitória, M. F. (2016). Elaboração e aplicação de descritores moleculares, morfológicos e físico-químicos para caracterização de germoplasma de mangabeira (65f. Dissertação, Mestrado em Agricultura e Biodiversidade, Universidade Federal de Sergipe São Cristovão, Sergipe, Brazil).

Yokomizo, G. K. I., Maia, M. C. C., \& Trindade, C. F. T. (2017). Morphological dissimilarity among mangabeira tree populations from Amapá and Paraíba, Brazil. Revista Caatinga, 30(2), 521-529. https://doi.org/ $10.1590 / 1983-21252017 \mathrm{v} 30 \mathrm{n} 228 \mathrm{rc}$

Yolcu, S., Ozdemir, F., Güler, A., \& Bor, M. (2016). Histone acetylation influences the transcriptional activation of POX in Beta vulgaris L. and Beta maritima L. under salt stress. Plant Physiology Biochemistry, 100, 37-46. https://doi.org/10.1016/j.plaphy.2015.12.019

\begin{abstract}
Abbreviations
AA: ascorbic acid; BAP: 6-benzylaminopurine; IAA: indole-3-acetic acid; IBA: indole-3-butyric acid; ISSR: inter simple sequence repeats; MS: Murashige and Skoog's medium; NAA: naphthalene acetic acid; HPLC: high performance liquid chromatography; DPPH: 2.2-diphenyl-1-picrilhydrazyl; Accessions: AB (Água Boa), BI (Barra do Itariri), CA (Costa Azul), CJ (Itaporanga), TC (Terra Caída) and PT (Pontal).
\end{abstract}

\title{
Copyrights
}

Copyright for this article is retained by the author (s), with first publication rights granted to the journal.

This is an open-access article distributed under the terms and conditions of the Creative Commons Attribution license (http://creativecommons.org/licenses/by/4.0/). 